\title{
Two-Arm Ferrocene Amide Compounds: Synclinal Conformations for Selective Sensing of Dihydrogen Phosphate Ion
}

\author{
Li-Jun Kuo, Jen-Hai Liao, Chao-Tsen Chen, ${ }^{*}$ Chien-Huang Huang, \\ Chien-Sheng Chen, and Jim-Min Fang *
}

Department of Chemistry, National Taiwan University, Taipei, 106, Taiwan

jmfang@ccms.ntu.edu.tw

Received February 28, 2003

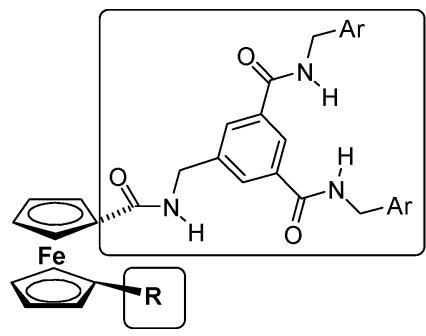

One-arm receptors $(\mathrm{R}=\mathrm{H})$ form

1:1 complexes with $\mathrm{H}_{2} \mathrm{PO}_{4}^{-}$ion.

Two-arm receptors $(R=$ the other arm)

in synclinal conformations form

1:2 complexes with $\mathrm{H}_{2} \mathrm{PO}_{4}{ }^{-}$ions.

Ferrocene compounds bearing multiple amido groups selectively bind with the $\mathrm{H}_{2} \mathrm{PO}_{4}{ }^{-}$ion over other anions. The one-arm receptors form 1:1 complexes with the $\mathrm{H}_{2} \mathrm{PO}_{4}{ }^{-}$ion, whereas the two-arm receptors can accommodate two $\mathrm{H}_{2} \mathrm{PO}_{4}{ }^{-}$ions. The complexation modes and binding strengths are deduced from the NMR, calorimetry, fluorescence, and cyclic voltammetry studies. The two-arm ferrocene hexamide receptors likely exist in synclinal conformations to incorporate tetrahydrofuran molecules and $\mathrm{H}_{2} \mathrm{PO}_{4}{ }^{-}$ions.

Selective sensing of anions is important in the biological, environmental, and supramolecular sciences. ${ }^{1}$ A chemical sensor consists of two basic parts: the recognition unit and the signal transduction unit. The synthetic receptors bearing several amine, amide, urea, thiourea, and quanidinium moieties have been demonstrated to bind or transport phosphate ions. ${ }^{2}$ The neutral receptors of amide, urea, and thiourea types are particularly interesting, because the transport of phosphate ions through the cell membrane is also regulated by neutral binding proteins.

(1) (a) Wiskur, S. L.; Ait-Hssou, H.; Lavigne, J. J.; Anslyn, E. V. Acc. Chem. Res. 2001, 34, 963. (b) Miyaji, H.; Sessler, J. L. Angew. Chem., Int. Ed. 2001, 40, 154. (c) Beer, P. D.; Gale, P. A. Angew. Chem., Int. Ed. 2001, 40, 486. (d) Sancenón, F.; Descalzo, A. B.; Martínez-Máñez, R.; Miranda, M. A.; Soto, J. Angew. Chem., Int. Ed. 2001, 40, 2640. (e) Snowden, T. S.; Anslyn, E. V. Curr. Opin. Chem. Biol. 1999, 3, 740. (f) Beer, P. D.; Cadman, J.; Lloris, J. M.; Martínez-Máñez, R.; Padilla, M. E.; Pardo, T.; Smith, D. K.; Soto, J. J. Chem. Soc., Dalton Trans. 1999, 127. (g) Beer, P. D.; Cadman, J. New J. Chem. 1999, 23, 347. (h) Beer, P. D Acc. Chem. Res. 1998, 31, 71. (i) de Silva, A. P.; Gunaratne, H. Q. N.; Gunnlaugsson, T.; Huxley, A. J. M.; McCoy, C. P.; Rademacher, J. T.; Rice, T. E. Chem. Rev. 1997, 97, 1515. (j) Schmidtchen, F. P.; Berger, M. Chem. Rev. 1997, 97, 1609. (k) Czarnik, A. W. Acc. Chem. Res. 1994, 27, 302. (1) Czarnik, A. W. Fluorescent Chemosensors for Ion and Molecule Recognition; American Chemical Society: Washington DC, 1992.
The redox-responsive units of ferrocene and other metallocenes have been incorporated into amide, urea, and quanidinium moieties to construct the anion receptors with electrochemical sensing properties. ${ }^{3}$ Upon oxidation of metallocene to the metallocenium state, the receptor will

(2) (a) Gunnlaugsson, T.; Davis, A. P.; O’Brien, J. E.; Glynn, M. Org. Lett. 2002, 4, 2449. (b) Hennrich, G.; Sonnenschein, H.; Resch-Genger, U. Tetrahedron Lett. 2001, 42, 2805. (c) Choi, K.; Hamilton, A. D. J. Am. Chem. Soc. 2001, 123, 2456. (d) Kubic, S.; Goddard, R.; Kirchner, R.; Nolting, D.; Seidel, J. Angew. Chem., Int. Ed. 2001, 40, 2648. (e) Lee, D. H.; Lee, K. H.; Hong, J.-I. Org. Lett. 2001, 3, 5. (f) Hossain, Md. A.; Llinares, J. M.; Powell, D.; Bowman-James, K. Inorg. Chem. 2001, 40, 2936. (g) Schneider, S. E.; O'Neil, S. N.; Anslyn, E. V. J. Am. Chem. Soc 2000, 122, 542. (h) Anzenbacher, P., Jr.; Jursíková, K.; Sessler, J. L. J. Am. Chem. Soc. 2000, 122, 9350. (i) Sasaki, S.; Mizuno, M.; Naemura, K.; Tobe, Y. J. Org. Chem. 2000, 65, 275. (j) Snellink-Ruël, B. H. M.; Antonisse, M. M. G.; Engbersen, J. F. J.; Timmerman, P.; Reinhoudt, D. N. Eur. J. Org. Chem. 2000, 165. (k) Cooper, J. B.; Drew, M. G. B.; Beer, P. D. J. Chem. Soc., Dalton Trans. 2000, 2721. (1) Kubo, Y.; Tsukahara, M.; Ishihara, S.; Tokita, S. Chem. Commun. 2000, 653. (m) Hayshita, T.; Onodera, T.; Kato, R.; Nishizawa, S.; Teramae, N. Chem. Commun. 2000, 755. (n) Werner, F.; Schneider, H.-J. Helv. Chim. Acta 2000, 83, 465. (o) Xie, H.; Yi, S.; Yang, X.; Wu, S. New J. Chem. 1999, 23, 1105. (p) Xiao, K. P.; Bühlmann, P.; Umezawa, Y. Anal. Chem. 1999, 71, 1183. (q) Watanabe, S.; Onogawa, O.; Komatsu, Y.; Yoshida, K. J. Am. Chem. Soc. 1998, 120, 229. (r) Hughes, M. P.; Smith, B. D. J. Org. Chem. 1997, 62, 4492. (s) Vance, D. H.; Czarnik, A. W. J. Am. Chem. Soc. 1994, 116, 9397. 
significantly enhance the binding strength with anions. Cyclic voltammetry $(\mathrm{CV})$ is often applied to measure the change of redox potentials, which can be correlated to the binding strengths. $^{3}$

Another convenient sensing method utilizes the direct optical readout of the change of color or fluorescence. We have previously devised a hexamide compound (1), ${ }^{4}$ which possesses a well-defined cleft to provide efficient multiple hydrogen bindings with $\mathrm{H}_{2} \mathrm{PO}_{4}{ }^{-}$and $\mathrm{PO}_{4}{ }^{3-}$ ions of tetrahedral shape. The pyrene moieties are also annexed to this phosphate receptor for a direct optical readout (Figure 1). ${ }^{5}$

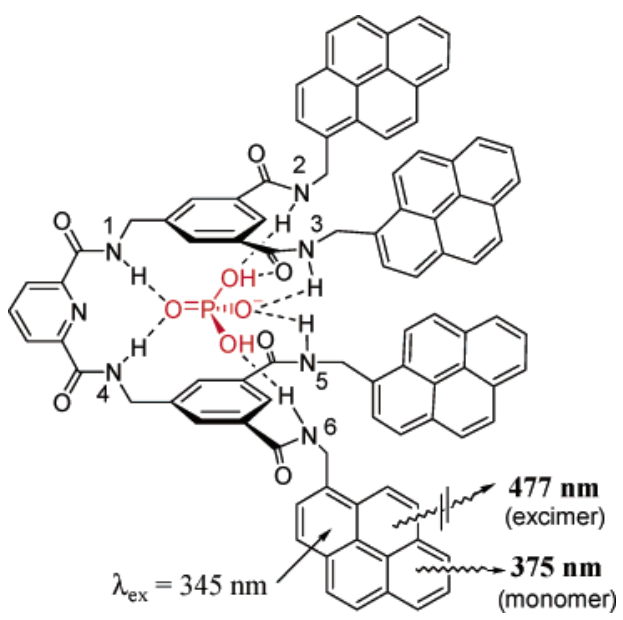

Figure 1. A model for the complexation of pyridine hexamide receptor $\mathbf{1}$ with dihydrogen phosphate ion. The pyrene moieties are pushed apart on complexation as shown by an increase of the monomer emission at $\lambda_{\max }=375 \mathrm{~nm}$ at the expense of the excimer emission at $\lambda_{\max }=477 \mathrm{~nm}$.

The complexation of phosphate ion and compound $\mathbf{1}$ with $1: 1$ binding stoichiometry can be readily quantified by a ratiometric fluorescence method, ${ }^{4}$ i.e., monitoring the simultaneous fluorescent changes between pyrene excimer $\left(\lambda_{\max }\right.$ $=477 \mathrm{~nm})$ and monomer $\left(\lambda_{\max }=375 \mathrm{~nm}\right){ }^{5}$

(3) (a) Reynes, O.; Gulon, T.; Moutet, J.-C.; Royal, G.; Saint-aman, E. J. Organomet. Chem. 2002, 656, 116. (b) Inouye, M.; Takase, M. Angew. Chem., Int. Ed. 2001, 40, 1746. (c) Carr, J. D.; Coles, S. J.; Hursthouse, M. B.; Light, M. E.; Tucker, J. H. R.; Westwood, J. Angew. Chem., Int Ed. 2000, 39, 3296. (d) Gallagher, J. F.; Kenny, P. T. M.; Sheehy, M. J. Inorg. Chem. Commun. 1999, 2, 327. (e) Buda, M.; Ion, A.; Moutet, J.-C.; Saint-Aman, E.; Ziessel, R. J. Electroanal. Chem. 1999, 469, 132. (f) Beer, P. D.; Graydon, A. R.; Johnson, A. O. M.; Smith, D. K. Inorg. Chem. 1997, 36, 2112. (g) Beer, P. D.; Drew, M. G. B.; Smith, D. K. J. Organomet. Chem. 1997, 543, 259. (h) Beer, P. D.; Graydon, A. R.; Sutton, L. R. Polyhedron 1996, 15, 2457. (i) Chen, Z.; Graydon, A. R.; Beer, P. D. J. Chem. Soc., Faraday Trans. 1996, 97.

(4) Liao, J.-H.; Chen, C.-T.; Fang, J.-M. Org. Lett. 2002, 4, 561.

(5) (a) Kim, J. S.; Shon, O. J.; Rim, J. A.; Kim, S. K.; Yoon, J. J. Org. Chem. 2002, 67, 2348. (b) Yang, J.-S.; Lin, C.-S.; Hwang, C.-Y. Org. Lett. 2001, 3, 889. (c) Jin, T. Chem. Commun. 1999, 2491. (d) Nishizawa, S.; Kato, Y.; Teramae, N. J. Am. Chem. Soc. 1999, 121, 9463. (e) Nishizawa, S.; Kaneda, H.; Uchida, T.; Terame, N. J. Chem. Soc., Perkin Trans. 2 1998, 2325. (f) Diamond, D.; McKervey, M. A. Chem. Soc. Rev. 1996, 15. (g) Takeshita, M.; Shinkai, S. Chem. Lett. 1994, 125. (h) Aoki, I.; Kawahara, Y.; Sakaki, T.; Harada, T.; Shinkai, S. Bull. Chem. Soc. Jpn. 1993, 66, 927. (i) Jin, T.; Ichikawa, K.; Koyama, T. Chem. Commun. 1992, 499. (j) Aoki, I.; Harada, T.; Sakaki, T.; Kawahara, Y.; Shinkai, S. Chem. Commun. 1992, 1341
A two-arm ferrocene amide receptor 7 was thus prepared (Figure 2), and its use as a molecular sensor for the $\mathrm{H}_{2} \mathrm{PO}_{4}{ }^{-}$
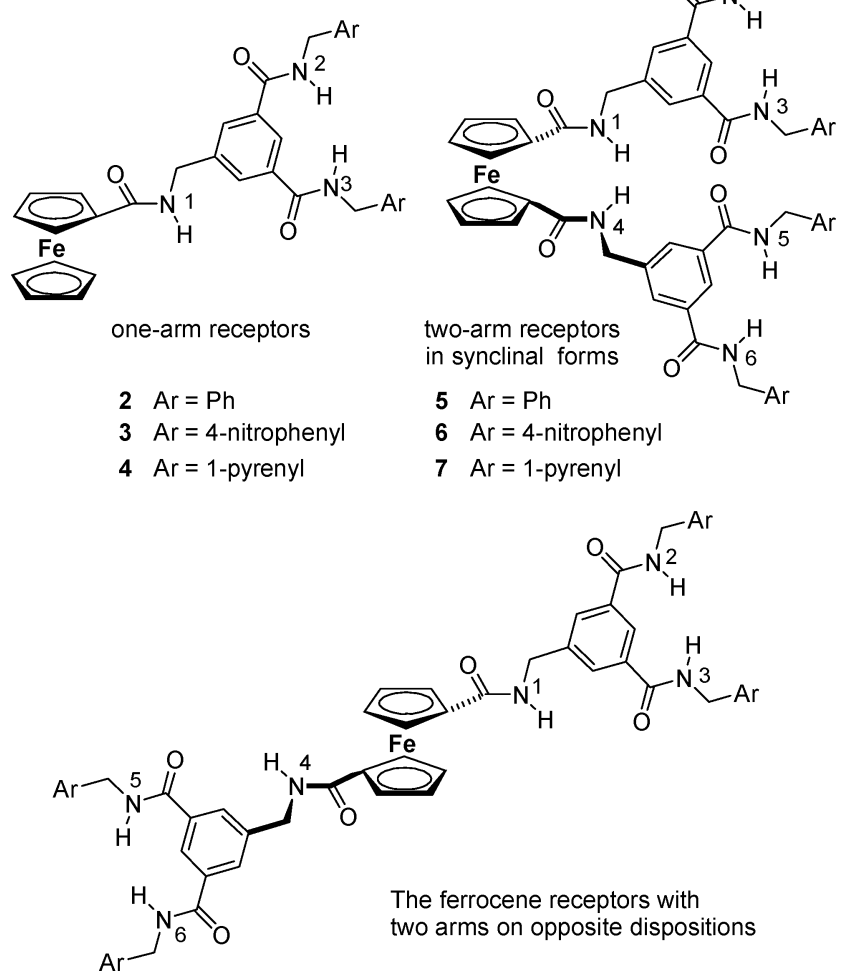

Figure 2. The structures of one-arm and two-arm ferrocene amide receptors for complexation with the $\mathrm{H}_{2} \mathrm{PO}_{4}{ }^{-}$anion. The synclinal and opposite dispositions of two arms in addition to other possible conformations in 5-7 are depicted. This study reveals that the two arms are likely on synclinal dispositions before and after complexation.

ion was examined. By replacing a pyridine moiety in compound 1 with the redox-responsive ferrocene unit, the binding property of 7 with the $\mathrm{H}_{2} \mathrm{PO}_{4}{ }^{-}$ion could be monitored by both electrochemical and optical methods. An especially interesting issue is the conformation of the $1,1^{\prime}$ disubstituted two-arm ferrocene receptor. Would these two arms dispose in the same, orthogonal, or opposite directions? Would the conformation change of this two-arm ferrocene receptor function as a pivotal switch on complexation with anions? The interactions of some other two-arm ferrocene amides (or the urea and thiourea analogues) with various anions have been reported ${ }^{3}$ however, the evidence for its preferable conformation in solutions is so far elusive. ${ }^{6}$

For comparison, we also prepared the one-arm ferrocene amides 2-4 and the two-arm analogues 5 and $\mathbf{6}$ (Figure 2). Compound 2 was prepared in $55 \%$ yield by condensation of ferrocenecarboxylic acid with $N, N^{\prime}$-dibenzyl-5-(aminomethyl)benzene-1,3-dicarboxamide 4 (8) in the presence of

(6) The X-ray crystal structure for a dimer of the complex of $N, N^{\prime}$ dipyridyl ferrocene-1,1'-dicarboxamide with glutaric acid has been reported in ref $3 \mathrm{c}$. 
EDCI, DMAP, and $\mathrm{Et}_{3} \mathrm{~N}$. Compounds $\mathbf{3}$ and $\mathbf{4}$ were similarly prepared in $80 \%$ and $53 \%$ yields. The direct condensation of ferrocene-1,1'-dicarboxylic acid with amine $\mathbf{8}$ did not afford the desired two-arm products in satisfactory yields. Thus, ferrocene-1,1'-dicarboxylic acid was activated to the corresponding acid chloride (using oxalyl chloride in pyridine) and then coupled with amine 8 to give compounds 5-7 in $95 \%, 72 \%$, and $55 \%$ yields, respectively.

The binding properties of ferrocene triamide 2 with a variety of anions were evaluated by the ${ }^{1} \mathrm{H}$ NMR studies in DMSO- $d_{6}$ solutions $\left(2 \times 10^{-3} \mathrm{M}\right)$. Upon addition of $\left(\mathrm{Bu}_{4} \mathrm{~N}\right)^{+} \mathrm{H}_{2} \mathrm{PO}_{4}^{-}(0.5-25$ equiv), the amide signals of 2 showed significant chemical-shift changes (see Supporting Information). The association constant $K_{\text {ass }}$ for the 1:1 complex of $2 \cdot \mathrm{H}_{2} \mathrm{PO}_{4}{ }^{-}$was estimated to be $189 \pm 5 \mathrm{M}^{-1}$ at $300 \mathrm{~K}$ by nonlinear regression. ${ }^{7}$ The binding of compound 2 with the $\mathrm{CH}_{3} \mathrm{CO}_{2}{ }^{-}$ion was relatively weak as shown by the similar ${ }^{1} \mathrm{H}$ NMR analyses. No significant binding with $\mathrm{Br}^{-}, \mathrm{NO}_{3}{ }^{-}, \mathrm{ClO}_{4}^{-}$, or $\mathrm{HSO}_{4}^{-}$anions was detected. The $\mathrm{CV}$ study (Figure 3) indicated that the oxidation potential of

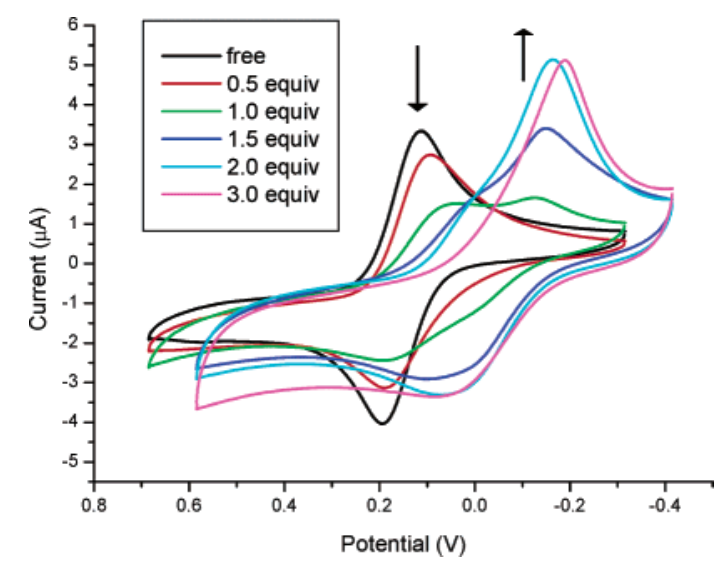

Figure 3. Cyclic voltammogram of ferrocene triamide 2. The redox potentials are calibrated with the standard ferrocene/ferrocenium ion system. The oxidation potential decreases on complexation with the $\mathrm{H}_{2} \mathrm{PO}_{4}{ }^{-}$ion $(0.5-3.0$ equiv). Scanning rate $=100 \mathrm{mV} / \mathrm{s}$.

compound 2 decreased on complexation with $\mathrm{H}_{2} \mathrm{PO}_{4}{ }^{-}\left(\Delta E_{1 / 2}\right.$ $=-126 \mathrm{mV}$ for 1:1 stoichiometry). A new wave appearing around $-0.2 \mathrm{~V}$ was attributable to the $2 \cdot \mathrm{H}_{2} \mathrm{PO}_{4}{ }^{-}$complex. ${ }^{3}$

By replacing the phenyl rings in compound 2 with $p$-nitrophenyl groups, the molecule $\mathbf{3}$ would exhibit more acidic amide protons, and thus form stronger hydrogen bindings with the $\mathrm{H}_{2} \mathrm{PO}_{4}^{-}$ion. Indeed, the association constant of $3 \cdot \mathrm{H}_{2} \mathrm{PO}_{4}^{-}\left(K_{\text {ass }}=247 \pm 14 \mathrm{M}^{-1}\right.$ at $\left.300 \mathrm{~K}\right)$ was larger than that of $2 \cdot \mathrm{H}_{2} \mathrm{PO}_{4}^{-}\left(K_{\text {ass }}=189 \pm 5 \mathrm{M}^{-1}\right)$ in DMSO- $d_{6}$ solution as indicated by the NMR analyses. The isothermal titration calorimetry (ITC) ${ }^{8}$ of the $\mathbf{3} \cdot \mathrm{H}_{2} \mathrm{PO}_{4}{ }^{-}$

(7) Connors, K. A. Binding Constants; Wiley: New York, 1987.

(8) (a) Haj-Zaroubi, M.; Mitzel, N. W.; Schmidtchen, F. P. Angew. Chem., Int. Ed. 2002, 41, 104. (b) Schmidtchen, F. P. Org. Lett. 2002, 4, 431. (c) Linton, B. R.; Goodman, M. S.; Fan, E.; van Arman, S. A.; Hamilton, A. D. J. Org. Chem. 2001, 66, 7313. (d) Linton, B.; Hamilton, A. D. Tetrahedron 1999, 55, 6027. complex in THF showed the association constant $K_{\text {ass }}=9100$ $\pm 1200 \mathrm{M}^{-1}$ at $300 \mathrm{~K}$ (see Supporting Information). The higher $K_{\text {ass }}$ value in THF solution, by comparison with that in DMSO, was in agreement with an expected stronger complexation in the less polar solvent. The ITC experiment showed not only a favorable enthalpy change $(\Delta H=-2.41$ $\pm 0.07 \mathrm{kcal} / \mathrm{mol})$ but also an increase of entropy $(\Delta S=10.2$ $\mathrm{cal} /(\mathrm{mol} \mathrm{K}))$ in the complexation of $\mathbf{3}$ with the $\mathrm{H}_{2} \mathrm{PO}_{4}{ }^{-}$ion. This result led to a speculation that the ferrocene triamide $\mathbf{3}$ might incorporate several THF molecules. ${ }^{8}$ On complexation with the $\mathrm{H}_{2} \mathrm{PO}_{4}{ }^{-}$ion, the bound THF molecules were thus liberated to account for the positive entropy change.

The fluorescent spectrum of the one-arm ferrocene amide receptor 4 showed pyrene monomer emissions at $\lambda_{\max }=375$, 387, and $398 \mathrm{~nm}$ in THF solution. No pyrene excimer emission at $\lambda_{\max }=477 \mathrm{~nm}$ was observed when the concentration of 4 was kept below $1 \times 10^{-6} \mathrm{M}$. It appeared that the two pyrene rings in $\mathbf{4}$ were not in a stacking position for excimer formation. This result was in agreement with our previous observation. ${ }^{4}$ On addition of the $\mathrm{H}_{2} \mathrm{PO}_{4}{ }^{-}$ion to a THF solution of $\mathbf{4}\left(1 \times 10^{-6} \mathrm{M}\right)$, the monomer emissions were somewhat enhanced as the concentration of the $\mathrm{H}_{2} \mathrm{PO}_{4}{ }^{-}$ ion increased. This result was attributed to the conformational rigidification on formation of the multiple hydrogen bonded $4 \cdot \mathrm{H}_{2} \mathrm{PO}_{4}{ }^{-}$complex. ${ }^{9}$ According to the NMR study, the complexation of $4 \cdot \mathrm{H}_{2} \mathrm{PO}_{4}{ }^{-}\left(K_{\text {ass }}=149 \pm 7 \mathrm{M}^{-1}\right.$ in DMSO$d_{6}$ solution at $300 \mathrm{~K}$ ) was slightly weaker than that of $2 \cdot \mathrm{H}_{2} \mathrm{PO}_{4}^{-}\left(K_{\text {ass }}=189 \pm 5 \mathrm{M}^{-1}\right)$ because the pyrene rings in 4 might exert a larger steric hindrance than the phenyl rings in 2 to disfavor the complexation with the $\mathrm{H}_{2} \mathrm{PO}_{4}{ }^{-}$ion.

Unlike the 1:1 complexation of the one-arm receptors $\mathbf{2}-\mathbf{4}$ with the $\mathrm{H}_{2} \mathrm{PO}_{4}^{-}$ion, the two-arm ferrocene hexamide receptors 5-7 formed the complexes with the $\mathrm{H}_{2} \mathrm{PO}_{4}{ }^{-}$ion in a 1:2 stoichiometry. The ${ }^{1} \mathrm{H}$ NMR titration experiments of compound $\mathbf{5}(\mathrm{Ar}=$ phenyl) showed the most significant chemical-shift changes of all the amide and ferrocene protons upon complexation with the $\mathrm{H}_{2} \mathrm{PO}_{4}{ }^{-}$ion. The complexation of 5 with various anions showed a trend similar to that for one-arm receptor 2, i.e., $\mathrm{H}_{2} \mathrm{PO}_{4}^{-}>\mathrm{AcO}^{-} \gg\left(\mathrm{I}^{-}, \mathrm{NO}_{3}{ }^{-}\right.$, $\mathrm{ClO}_{4}^{-}, \mathrm{HSO}_{4}^{-}$).

The ITC analyses for complexation of 6 with the $\mathrm{H}_{2} \mathrm{PO}_{4}{ }^{-}$ ion revealed the association constants, $K_{1}=197000 \pm$ $57000 \mathrm{M}^{-1}$ and $K_{2}=8300 \pm 1100 \mathrm{M}^{-1}$ at $300 \mathrm{~K}$ in THF solution (Figure 4). By comparison with the association constant of $\mathbf{3} \cdot \mathrm{H}_{2} \mathrm{PO}_{4}^{-}\left(9100 \pm 1200 \mathrm{M}^{-1}\right)$, the two-arm receptor 6 appeared to bind much more strongly with the $\mathrm{H}_{2} \mathrm{PO}_{4}{ }^{-}$ion. It was noted that the complexation was also synergistically driven by negative enthalpy changes $\left(\Delta H_{1}\right.$ $=-3.25 \pm 0.03$ and $\Delta H_{2}=-2.22 \pm 0.08 \mathrm{kcal} / \mathrm{mol}$ ) and positive entropy change $\left(\Delta S_{1}=12.6\right.$ and $\Delta S_{2}=10.1 \mathrm{cal} /$ $(\mathrm{mol} \mathrm{K}))^{8}$

The fluorescence spectrum (by excitation at $345 \mathrm{~nm}$ ) of the two-arm receptor 7 showed emissions for both the monomer and the excimer of pyrene moieties (Figure 5). As the intensity ratio of monomer/excimer emissions remained constant in various concentrations $\left(10^{-7}-10^{-6} \mathrm{M}\right)$,

(9) (a) McFarland, S. A.; Finney, N. S. J. Am. Chem. Soc. 2002, 124, 1178. (b) Choi, K.; Hamilton, A. D. Angew. Chem., Int. Ed. 2001, 40, 3912. 


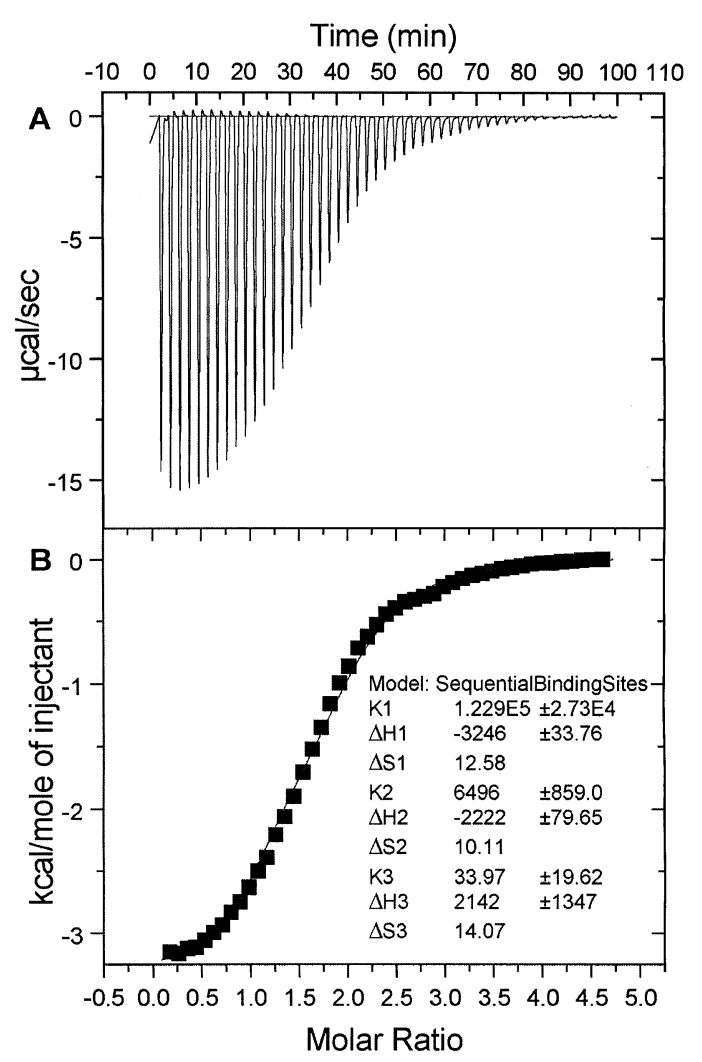

Figure 4. Isothermal titration calorimetry for complexation of the two-arm ferrocene hexamide receptor $6(1 \mathrm{mM})$ with the $\mathrm{H}_{2} \mathrm{PO}_{4}{ }^{-}$ ion $(20.9 \mathrm{mM})$ at $300 \mathrm{~K}$ : (A) the raw data obtained for 48 automatic injections, each of $6 \mu \mathrm{L}$, of the $\mathrm{H}_{2} \mathrm{PO}_{4}{ }^{-}$ion and (B) the integrated curve showing experimental points and the best fit values of the parameter, $n=3$, with sequential binding sites.

the excimer emission should occur via intramolecular interactions of pyrenes, but not intermolecularly. This assertion is supported by the lack of excimer emission in the one-arm receptor 4 . We have previously proved that the excimer emission of compound $\mathbf{1}$ (Figure 1) is derived from the interaction of the pair of $N_{2}$ - and $N_{5}-\mathrm{CH}_{2}$-pyrenes (or $N_{3^{-}}$and $N_{6}-\mathrm{CH}_{2}$-pyrenes). ${ }^{4}$ The excimer emission of compound 7 should occur similarly via the stacking of the pair of pyrenes on different arms, rather than the pyrenes on the same arm.

By comparison with compound $\mathbf{1}$, the ratio of excimerto-monomer emission intensity in compound $\mathbf{7}$ was lower, i.e., $I_{\text {excimer }} / I_{\text {monomer }} \sim 1.2$ in compound 7 vs $\sim 5.5$ in compound $1 .{ }^{10}$ This phenomenon presumably reflected a partial energy transfer of pyrene excimer $\left(\lambda_{\max }=477 \mathrm{~nm}\right)$ to the ferrocene moiety that has an absorption of $\sim 450$ nm. ${ }^{3 f, 11}$ Nevertheless, the fluorescence spectroscopy was still

(10) The excimer emission intensity was estimated by taking the area of fluorescence in the wavelength region of $430-600 \mathrm{~nm}$, whereas the monomer emission intensity was estimated by taking the area of fluorescence in the wavelength region of $350-430 \mathrm{~nm}$.

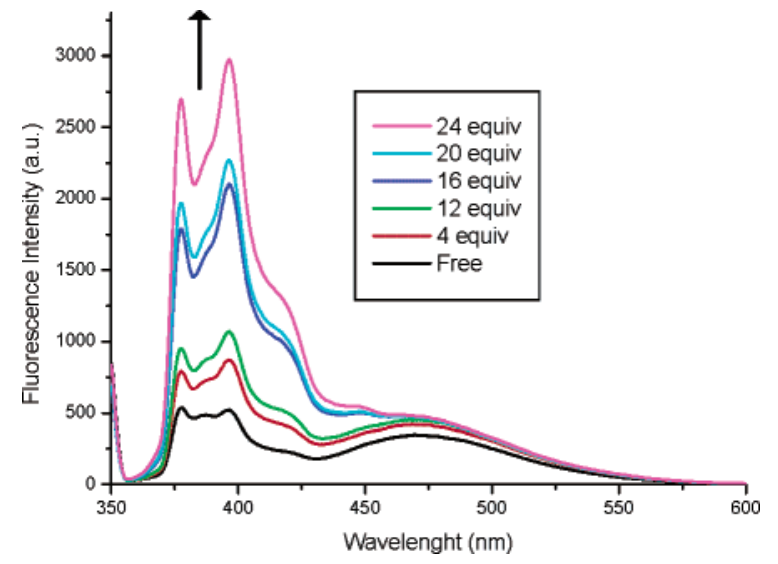

Figure 5. Fluorescence titration spectra of the two-arm receptor 7 $\left(1 \times 10^{-6} \mathrm{M}\right.$ in THF solution) with the $\mathrm{H}_{2} \mathrm{PO}_{4}{ }^{-}$ion. Addition of $\left(\mathrm{Bu}_{4} \mathrm{~N}\right) \mathrm{H}_{2} \mathrm{PO}_{4}$ resulted in enhanced fluorescence.

a useful tool for detection of the $\mathrm{H}_{2} \mathrm{PO}_{4}{ }^{-}$ion. The complexation of 7 with the $\mathrm{H}_{2} \mathrm{PO}_{4}{ }^{-}$ion was easily monitored by the enhanced fluorescence, especially the obvious changes of the monomer emissions (Figure 5).

On the basis of our present studies, particularly the evidence from the ITC measurements and fluorescence spectra, compound $\mathbf{7}$ and other two-arm ferrocene hexamide molecules likely have synclinal conformations in THF solution. The synclinal conformation could be stabilized by incorporation of THF molecules or by complexation with $\mathrm{H}_{2} \mathrm{PO}_{4}{ }^{-}$ions. The more compact eclipsed conformation is disfavored because its cleft would be too small to adapt two $\mathrm{H}_{2} \mathrm{PO}_{4}{ }^{-}$ions for complexation.

In summary, we have prepared ferrocene compounds $\mathbf{2}-\mathbf{7}$ with multiple amido groups that bind with the $\mathrm{H}_{2} \mathrm{PO}_{4}{ }^{-}$ion selectively over other anions $\left(\mathrm{AcO}^{-}, \mathrm{I}^{-}, \mathrm{NO}_{3}{ }^{-}, \mathrm{ClO}_{4}{ }^{-}\right.$, and $\mathrm{HSO}_{4}{ }^{-}$). The one-arm receptors $\mathbf{2}^{-4}$ form 1:1 complexes with the $\mathrm{H}_{2} \mathrm{PO}^{-}$ion, whereas the two-arm receptors 5-7 can accommodate two $\mathrm{H}_{2} \mathrm{PO}_{4}{ }^{-}$ions. The complexation modes, binding strengths, and sensing properties are demonstrated by the NMR, ITC, CV, and fluorescence studies.

Acknowledgment. We thank the National Science Council for financial support.

Supporting Information Available: Detailed experimental procedures, physical and spectral data for compounds 2-7, NMR, fluorescence, and isothermal calometric titrations. This material is available free of charge via the Internet at http://pubs.acs.org.

\section{OL034364I}

(11) To support this speculation, we also found that the 477-nm excimer band of compound $\mathbf{1}$ dramatically decreased upon addition of ferrocene. 